\title{
Broiler Pre-Slaughter Water Diet with Grass Lemongrass (Cymbopogon Citratus Stapf)
}

\section{-Author(s)}

Garcia RG'
Royer $A F^{\prime}$
Nääs $\left.\right|^{\prime}$
Borille $R^{\prime}$
Santana $M^{\prime}$
Caldara FR'
' Federal University of Grande Dourados,
FCA, Dourados, MS- Brazil

\section{Mail Address}

Corresponding author e-mail address Rodrigo Garófallo Garcia

Federal University of Grande Dourados, FCA, Rod. Dourados-Itahum km 12, 79804970, Dourados, MS, Brazil

Tel: $\quad$ (5567) 34102437

Email: rodrigogarcia@ufgd.edu.br

\section{- Keywords}

Meat, welfare, phytotherapy, pre-slaughter, meat quality.

\section{ABSTRACT}

The pre-slaughter management is one of the predisposing factors to the reduction in the quality of the carcass and broiler meat, mainly for being a stressful condition. This study evaluates the inclusion of lemongrass (Cymbopogon citratus Stapf) in the water used in the diet of pre-slaughter broilers for the first time. The carcass and meat quality parameters were evaluated. The experiment was carried out in the poultry production of an experimental sector of the Federal University of Grande Dourados - UFGD. A total of 2,594 broilers were distributed in an entirely randomized design in a factorial arrangement of $3 \times 2 \times 2$, with three different lemongrass concentrations in the form of infusion (0. 1 and $5 \mathrm{~g} / \mathrm{L}$ ), two sexes and two genetic strains (Ross $308^{\circledR}$ and Cobb $500^{\circledR}$ ), and with four replications. After 42 days, 144 broilers were slaughtered, and the quality parameters of carcass and meat were evaluated. A higher incidence of scratches and higher water retention capacity were found in Ross $308^{\circledR}$ male $(p<0.05)$. Less exudate of breast fillets loss was observed in broiler Ross $308^{\circledR}$ males $72 \mathrm{~h}$ post-mortem $(p<0.05)$. There was an interaction between sex and lemongrass levels in the drinking water of the broilers in the sensory analysis of meat $(p<0.05)$, more preferably of chewiness and juiciness for males undergoing free diet for juiciness and lemongrass in the female diet with $5 \mathrm{~g} / \mathrm{L}$. The use of lemongrass infusions in pre-slaughter did not bring considerable benefits to the quality of carcass and meat of broiler.

\section{INTRODUCTION}

The pre-slaughter handling is characterized by catching and transportation of broilers. It is a stressful situation for the animals, with the release of fear and panic reactions that interfere with the welfare conditions and, in some cases, results in economic losses, such as the increase in mortality levels and the incidence of scrapes in the carcass (Paranhos da Costa, 2008). Carcass quality can be affected by various aspects such as age, sex, nutrition, management, temperature, time of fasting, and methods of harvesting and transportation (Mendes \& Komiyama, 2011). Issues during collection and transportation might be directly related to the animals' welfare and might lead to abnormal biochemical changes during the transformation of the muscle meat. As a consequence, it results in the acceleration of glycolysis reactions altering the quality of characteristics and promoting the occurrence of meat PSE (Pale, Soft, Exudative) with a pale, soft and exudative appearance (Bressan \& Beraquet, 2002).

As a result, there is a need for studies aiming at reducing the impact of pre-slaughter and the adoption of low-cost management practices, offering sustainable alternatives to the producers. Several plants might affect the behavior and the mechanisms of action of individuals, in which anxiety and stress disorders are the main factors for researching and for 
the development of new pharmacotherapies (Rocha et al., 2008). From their extracts and constituents, it might be possible to find positive effects on the welfare relationship and poultry production on an industrial scale. Some plants have anxiolytic potential and are widely used in human therapeutic. The grass lemongrass (Cymbopogon citratus Stapf) is a species of medicinal plants commonly used in folk medicine in Brazil for its calming and sedative purposes and action on the central nervous system. However, in animal production research it is practically nonexistent (Negrelle \& Gomes, 2007). This study aimed to evaluate the use of lemongrass the in water of broiler diets during the pre-slaughter on carcass and meat quality parameters.

\section{MATERIAL AND METHODS}

This study was carried out in the Experimental Poultry Sector of the Federal University of Grande Dourados - UFGD using 2594 broilers. The birds were distributed in an entirely randomized design in a factorial arrangement of $3 \times 2 \times 2$, with three different levels of dried and ground lemongrass grass (Cymbopogon citratus Stapf) in the form of infusion $(0,1$ and $5 \mathrm{~g}$ of dry powder $\mathrm{L}$ water). The beverage was tested in two sexes, and two lineages (Ross $308^{\circledR}$ and Cobb $500^{\circledR}$ ) with four replicates with 54 broilers. The broilers were conventionally grown according to the manual of the genetic strain under study, and the supply of grass lemongrass infusions in different concentrations was performed ad libitum, during the fasting of the birds before slaughter at 42 days of age.

Infusions of lemongrass (Cymbopogon citratus) were prepared from the immersion of dried and ground grass in water at a temperature of $100^{\circ} \mathrm{C}$ and left to rest until complete cooling, with subsequent filtering (Cruz et al., 2007). The infusions were administrated to the broilers during the fasting during six hours. Subsequently, twelve broilers were separated per treatment, properly harvested by the back, identified, and accommodated in the transport boxes and sent to the Meat Technology Laboratory. Conventional slaughtering procedures in the poultry industry were adopted, and whole and hot carcasses were evaluated for the presence and absence of gathering, transporting and growing scratches (Pilecco et al., 2011). Subsequently, the breast sections were deboned, separating the Pectoralis major, and other muscle samples were kept under refrigeration $\left(2^{\circ} \mathrm{C}\right)$ to the achievement of the quality analysis. The assessment of the $\mathrm{pH}$ of the broiler breast fillets was performed at 4, 12, 24 and 48 hours post-mortem using a pHmeter (Hanna bench pH-meter, pH 21 Model pH/MV) calibrated with two standards ( $\mathrm{pH} 4.0$ and $\mathrm{pH}$ 7.0). An incision was made at the top of the sample for the introduction of the electrode.

Table 1 - Colorimetry Pectoralis major muscle broiler subjected to water diet with lemongrass (Cymbopogon citratus Stapf) in the form of infusion in three concentrations.

\begin{tabular}{lccc}
\hline Treatment & \multicolumn{3}{c}{ Colorimetry } \\
\cline { 2 - 4 } & $\mathrm{a}^{*}$ & $\mathrm{~b}^{*}$ & $\mathrm{~L}^{*}$ \\
\hline Gender & 12.2 & 19.4 & 55.9 \\
Male & 12.1 & 20.6 & 56.8 \\
\hline Female & & & \\
\hline Geneticstrain & 12.2 & 19.6 & 56.1 \\
Ross 308 & & & \\
Cobb 500 & & & \\
\hline Level & 12.1 & 20.3 & 56.6 \\
0 & & & 56.4 \\
1 & 12.0 & 20.2 & 56.1 \\
5 & 12.3 & 20.1 & 56.6 \\
\hline CV\% & 12.1 & 19.6 & 0.11 \\
\hline
\end{tabular}

Means were compared by the Tukey test using 95\% confidence level.

The evaluation of the loss of exudate was performed using six breast meat samples by treatment, kept under retailing sale simulation in polyethylene trays covered with a plastic film, the $3 \pm 1{ }^{\circ} \mathrm{C}$ for 24,48 and 72 h. From each tray, exudate was discarded, and samples were weighed on an analytical balance, maintaining the trays and weighing samples for the following time. The loss of exudate was obtained by the difference between the initial and final weights of samples and expressed as percentage loss in the initial sample weight. The water retention capacity was done following the method described by Hamm (1960), by evaluating six breast meat samples with 24, 48 and 72 $\mathrm{h}$ post-mortem. The process is done by removing two grams of each sample meat in the form of cubes and placed between two circular filter paper then placed between two glass plates which received $10 \mathrm{~kg}$ for five minutes to determine the quantity of water released under pressure weight on muscle tissue. After pressing, the sample was weighed, and the result expressed in percentage of water exuded from the initial sample weight.

The color of the broilers fillets was measured using portable colorimeter Minolta CR 400 model, with results shown in CIELab system, light source D65 and angle of $10^{\circ}$. The evaluation was done on the lower part of the muscle Pectoralis major after the removal of the Pectoralis minor. The values of $L$ * (lightness), a * (red intensity) and $b$ * (yellow intensity) were assessed measured at two different places in the lower ventral 
region of the muscle, by calculating the average of the values obtained.

The weight loss on cooking was determined to six broilers breast fillets by treatment, weighed on an analytical balance and baked in an electric oven at $180^{\circ} \mathrm{C}$ for 16 minutes (eight minutes/side) until reaching an inside temperature of $82^{\circ} \mathrm{C}$, measured with digital thermometer skewer. Later they were cooled at ambient temperature and weighed and the difference between the initial and final weight corresponded to the cooking weight loss expressed as percentage loss compared to the initial weight. The cooked fillets were used to determine the shear force, by removing three cubes of $2 \times 2 \times 1.13 \mathrm{~cm}$ of the breast fillet and placing them in the texture meter device (TAXT $2 \mathrm{i}$ Stablemicro Systems). The fibers were oriented in a perpendicular direction to the Warner-Blatzler blades of the apparatus, measuring up the strength to cut them with a value expressed in $\mathrm{kgf}$ for $\mathrm{cm}^{2}$.

The sensory evaluation of meat was done at the Agricultural Sciences in Animal Products Technology Laboratory applying sufficient proof through the acceptance test with verbal hedonic scale, numeric, bipolar five-point, with the participation of 41 inexperienced tasters. The evaluated attributes were the softness (texture to the touch and chewing), the color (appearance) and the acceptance (odor, juiciness, and flavor) getting scores about the approval of the tester through inductive questionnaire activity (Zenebon et al., 2008).

The meat samples were distributed in six treatments, based on the results obtained by Takahashi et al. (2012) who used only the factors of sex and lemongrass levels for the evaluation, and eliminated the role of genetic strain on the sensory characteristics. Therefore, fatigue was avoided by too many tests and maintaining an appropriate number of repetitions (Torres et al., 2011). The breast samples previously kept in a freezer $\left(-18^{\circ} \mathrm{C}\right)$ were unfrozen, wrapped with aluminum foil and taken to the oven until they reached an internal temperature of $82^{\circ} \mathrm{C}$ measured with a digital thermometer. After cooking, the meat was cut into cubes measuring 1 $x 1 \mathrm{~cm}$ (Torres et al., 2011). The pieces were packed in foil and heated for the tasters, instructed to point at the scale of 1 to 5 the samples that showed better characteristics for the evaluated parameters, considering 1 for the worst sample and 5 for the best one (Zenebon et al., 2008).

The model of the analysis assumption (data additivity, homoscedasticity, and normality) was performed on the results and tested for all traits. Those features that met the assumptions were analyzed using the one-way analysis of variance (ANOVA). The means were compared using the Tukey test for the carcass and meat characteristics. Those elements which did not meet the suppositions were treated as non-parametric and further analyzed using the Kruskal-Wallis test (Delgado-Suárez et al., 2016). Data were processed using the Software Core Team ${ }^{\circledR}$ (Core Team R, 2012). Reported differences were significant at the 0.05 level.

The research was approved by the Ethics Committee on Animal Use of UFGD with protocol number 007/2012.

\section{RESULTS}

No interactions were found amongst the factors sex, lineage, and lemongrass levels; however, there was a higher incidence of scratches on the carcasses of males, and a greater frequency of scratches to the genetic strain Ross $308^{\circledR}(p<0.05)$ (Figure 1). Amongst the tested lemongrass levels, the incidence of scratches varied between treatments, not ensuring the influence of a degree of quality of carcasses, and the presence of bruising in carcasses was not observed. However, broilers which received the infusion had a lower incidence of unhealed scratches (Figure 1). The $\mathrm{pH}$ values did not differ ( $p>0.05)$ between treatments obtaining average values between 5.9 and 6.3. The $L^{*}$, $a^{*}$, and $b^{*}$ meat color parameters were similar in the treatments ( $p>0.05)$.

Figure 1 - Results of the frequency of scratches in broiler carcasses.

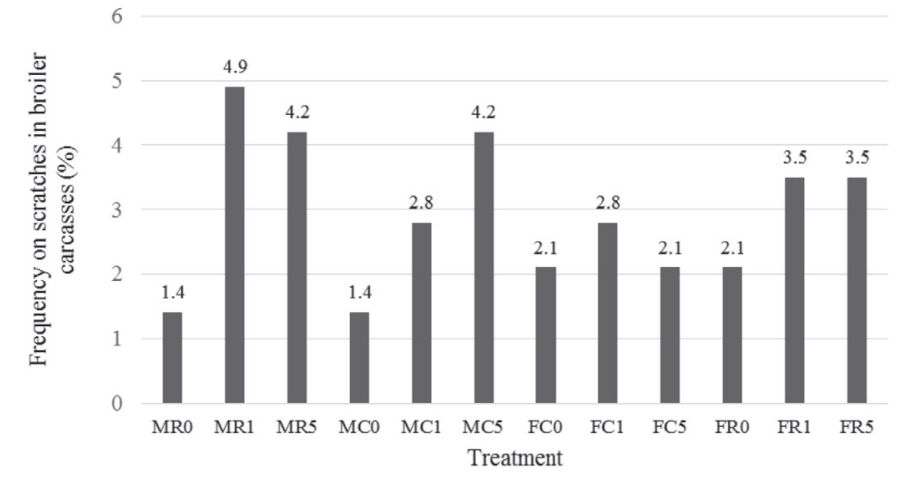

(MRO - Males Ross 308 ${ }^{\circledR}$ Og; MR1 - Males Ross 308 ${ }^{\circledR} / 1 \mathrm{~g}$; MR5 - Males Ross 308 / 5g; MCO - Male Cobb 500 ${ }^{\circledR}$ Og; MC1 - Male Cobb 500 ${ }^{\circledR} / 1 \mathrm{~g}$, MC5 - Males Cobb 500 / 5g; FCO - Females Cobb 500 ${ }^{\otimes} / 0$ g; FC1 - females Cobb 500 / 1 g; FC5 - females Cobb 500 / 5g; FRO - females Ross 308 ${ }^{\circledR} / 0 \mathrm{~g}$; FR1 - Female Ross 308® / $1 \mathrm{~g}$; FR5 - Ross Female 308 ${ }^{\oplus / 5 g}$ ).

There was no difference among treatments for water retention capacity of the fillets $48 \mathrm{~h}$ post-mortem ( $p>0.05)$. However, the genetic strain interfered with 
the water retention capacity of $72 \mathrm{~h}$ post-mortem $(p<0.05)$ higher water retention capacity obtained in the genetic strain Ross $^{\circledR} 308$ (Table 2). The lemongrass levels in drinking water and the genetic strain of the broiler did not affect the weight loss by exudation of meat ( $p>0.05$ ). However, regarding sex, the male breast fillets showed less weight loss exudate when compared to females at $72 \mathrm{~h}$ post-mortem. There was no effect of treatments on weight loss by cooking ( $p>0.05)$, and shear strength of the chest fillets evaluated (Table 2 ).

Table 2 - Loss of exudate (PE), water holding capacity (WHC), weight loss by cooking (PPC) and shear force (FC) muscle Pectoralis major broiler subjected to water diet with lemongrass (Cymbopogon citratus Stapf).

\begin{tabular}{|c|c|c|c|c|c|c|c|}
\hline \multirow[t]{2}{*}{ Treatment } & \multicolumn{3}{|c|}{$\mathrm{PE}(\%)$} & \multicolumn{2}{|c|}{ CRA (\%) } & \multirow[t]{2}{*}{ PPC (\%) } & \multirow{2}{*}{$\begin{array}{c}\mathrm{FC} \\
\left(\mathrm{kgf} / \mathrm{cm}^{2}\right)\end{array}$} \\
\hline & $24 \mathrm{~h}$ & $48 \mathrm{~h}$ & $72 \mathrm{~h}$ & $48 \mathrm{~h}$ & $72 \mathrm{~h}$ & & \\
\hline \multicolumn{8}{|l|}{ Gender } \\
\hline Males & 1.8 & $2.7 \mathrm{~b}$ & $4.5 \mathrm{~b}$ & 38.1 & 36.4 & 19.8 & 2.1 \\
\hline Female & 2.1 & $3.5 \mathrm{a}$ & $5.3 \mathrm{a}$ & 38.5 & 31.7 & 19.1 & 2.3 \\
\hline \multicolumn{8}{|c|}{ Geneticstrain } \\
\hline Ross 308 $8^{\circledR}$ & 2.1 & 3.1 & 5.2 & 39.1 & $37.6 \mathrm{a}$ & 20.4 & 2.1 \\
\hline Cobb $500^{\circledR}$ & 1.8 & 3.2 & 4.7 & 37.6 & $30.5 b$ & 18.5 & 2.1 \\
\hline \multicolumn{8}{|l|}{ Level } \\
\hline 0 & 2.0 & 2.9 & 4.9 & 31.4 & 36.6 & 20.2 & 2.0 \\
\hline 1 & 2.1 & 3.3 & 4.8 & 41.8 & 32.9 & 19.8 & 2.2 \\
\hline 5 & 1.7 & 3.2 & 5.1 & 41.8 & 32.1 & 18.4 & 2.3 \\
\hline CV\% & 38.0 & 9.9 & 13.5 & 35.2 & 33.8 & 0.8 & 0.3 \\
\hline
\end{tabular}

Means with different letters in the column are significantly different by Tukey test $(p<0.05)$.

There was an interaction between sex and lemongrass levels in the broilers drinking water on the sensory analysis of the meat $(p<0.05)$, except for variable flavor (Table 3). Fillets of males showed the influence of lemongrass levels on chewiness and juiciness of the meat $(p<0.05)$, observing best chewiness and juiciness in samples from broilers that did not receive the lemongrass in pre-slaughter. The meat from the

Table 3 - Sensory analysis Pectoralis major muscle broiler submitted to water diet with lemongrass (Cymbopogon citratus Stapf) in the form of infusion in three concentrations.

\begin{tabular}{|c|c|c|c|c|}
\hline \multicolumn{5}{|c|}{ Appearance } \\
\hline Gender & 0 & 1 & 5 & Average gender \\
\hline Female & 3.3 & 3.4 & 3.6 & 3.3 \\
\hline Male & 3.5 & 3.2 & 3.1 & 3.4 \\
\hline Average Level & 3.4 & 3.3 & 3.3 & - \\
\hline \multicolumn{5}{|c|}{ Fragrance } \\
\hline & 0 & 1 & 5 & Average gender \\
\hline Female & 3.5 & 3.7 & 3.4 & 3.5 \\
\hline Male & 3.6 & 3.5 & 3.7 & 3.6 \\
\hline Average Level & 3.6 & 3.6 & 3.6 & - \\
\hline \multicolumn{5}{|c|}{ Chewiness } \\
\hline & 0 & 1 & 5 & Average gender \\
\hline Female & 3.8 & 3.8 & 3.9 & 3.8 \\
\hline Male & $4.3 \mathrm{a}$ & $3.7 \mathrm{~b}$ & $3.6 b$ & 3.9 \\
\hline Average Level & 4.1 & 3.8 & 3.8 & - \\
\hline \multicolumn{5}{|c|}{ Succulence } \\
\hline & 0 & 1 & 5 & Average gender \\
\hline Female & $3.2 \mathrm{~b}$ & $3.2 \mathrm{~b}$ & $3.7 \mathrm{a}$ & 3.4 \\
\hline Male & $3.7 \mathrm{a}$ & $3.1 \mathrm{~b}$ & $2.8 b$ & 3.2 \\
\hline Average Level & 3.5 & 3.2 & 3.3 & - \\
\hline \multicolumn{5}{|c|}{ Flavor } \\
\hline \multirow[t]{2}{*}{ Gender } & & \multicolumn{2}{|l|}{ Female } \\
\hline & & 3.6 & \multicolumn{2}{|l|}{3.6} \\
\hline \multirow[t]{2}{*}{ Level } & 0 & 1 & \multicolumn{2}{|r|}{5} \\
\hline & 3.6 & 3.5 & & 3.6 \\
\hline
\end{tabular}

Means with different letters in the line are significantly different by Kruskal-Wallis test $(p<0.05)$. 
females which drank the lemongrass infusion of $5 \mathrm{~g}$ per $L$ presented greater juiciness $(p<0.05)$ than the other meat tested. No difference was identified between the sexes and lemongrass levels when tested isolated $(p>0.05)$.

\section{DISCUSSION}

The results obtained in the incidence of scratching on the carcasses of males agree with the results achieved by Pilecco et al. (2011). The author related a high frequency of injuries and the final weight difference between the sexes of broilers, since the females have lower mass than the males, and getting more space in the rearing and transport, besides being less disposed to cramping. The weight difference between the sexes has been reported in the literature, especially from the $21^{\text {st }}$ of grow-out (Santos et al., 2005). The highest incidence of scratches on Ross $308^{\circledR}$ genetic strain might be justified by the different behavior shown by the genetic strains when in stressful situations. Ross $308^{\circledR}$ broilers exposed to high temperatures in a study developed by Pereira et al. (2007) were more active than those from the Cobb $500^{\circledR}$ genetic strain. This behavior might occur because of the metabolic acceleration seen in broilers in stressful conditions (Roque-Specht et al., 2009). Thus, the increase of scratches on Ross $308^{\circledR}$ can be related to the stacking of broilers during transportation within boxes in search for the sides for a more efficient thermal exchange.

The absence of bruising on the carcass might be related to the transport period used in the present study, when the boilers were carried out in the morning. According to Barbosa Filho et al. (2009), during the morning and the night shift, a significant region of thermal comfort throughout the load profile was observed. Thus, the best time for transportation of broilers is during the morning and night shifts since this period of the day provide more favorable environmental conditions for the pre-slaughter operation.

The average $\mathrm{pH}$ values between 5.9 and 6.3 are close to the values of 5.94 and 6.01 found by Pavan et al. (2003). The pH values below 5.6 might cause the development of meat with PSE characteristics (pale, soft, exudative) in chickens. A rapid decrease in $\mathrm{pH}$ causes denaturation of myofibrillar proteins and sarcoplasmic leading to excessive loss of exudate and resulting in pale meat by the increase of the birefringence of muscle fibers (Droval, 2011). Therefore, the $\mathrm{pH}$ isolated is not alone efficient to diagnose PSE in meat, but the association with the color, loss of exudate and water capacity retention in meat (Lara et al., 2003).
Similar results to those found in the present work for the values of $L^{*}, a^{*}$, and $b^{*}$ were described by Santos et al. (2005) where the genetic strain and sex also did not interfere in the meat color parameters. The color can be influenced by several factors such as enzymes, diet, the age of the animal and events before slaughter. The pallor is associated with protein denaturation caused by low $\mathrm{pH}$ and high carcass temperature (Droval, 2011). According to Fragoso (2012), the meat surface color is the result of selective absorption of wave lengths of light that emerges from the meat with the natural pigments and the meat fibers. This characteristic is dependent on the amount of heme pigment (myoglobin, hemoglobin, and cytochrome C) absorbsion of all track colors except the range between 630-780 nanometers, corresponding to red, which is reflected in the eyes (Cornforth, 1994; Praxedes, 2007). By decreasing $\mathrm{pH}$, protein denaturation and expulsion of water, the protein-protein interaction increases and the occurrence of the birefringence of the fibers with less light being transmitted through the meat and more light is scattered due to heme pigment susceptibility to chemical changes, modifying the capacity to absorb the incident light rays present in the meat. Thus, there is a reduction of the perception of red in the meat causing paleness (Fragoso, 2012).

The water retention capacity is related to the sudden fall of the $\mathrm{pH}$ during glycolysis post-mortem (Ribeiro, 2008). According to Maganhini et al. (2007) physical exercise, transportation, movement and prolonged fasting involves the consumption of the glycogen reserves, leading to slow glycolysis with the relatively increased formation of muscle lactic acid and a slight reduction in $\mathrm{pH}$ in the first hours. There is a subsequent stabilization that remains at higher levels 6.01. This fact makes the muscle proteins retain a great capacity to keep water inside the cells. This effect justifies the water retention capacity presented in Ross $308^{\circledR}$ broilers considering the little ability to adapt to stressful situations and greater movement during catching and transportation when compared to Cobb $50{ }^{\circledR}$ (Pereira et al., 2007). Results of Mollete et al. (2003) showed broilers breast cuts considered normal with a water retention capacity greater than $62.5 \%$. The values obtained for water retention capacity of the present study are below these values, as well as those obtained by Huallanco (2005) (54\%). However, it does not characterize PSE cuts, since the original classification depends on $\mathrm{pH}$ values of less than 5.6, which was not observed in this study.

Distinctly perceived in the present study, Moreira et al. (2003) found no influence of sexes on the quality 
of meat of different lineages evaluated. Schneider et al. (2005) describe a loss of normal exudate cuts of $2.55 \%$, but as the weight loss by cooking and shear strength, the loss of exudate muscle is related to water retention capacity. However, regarding the genetic strain effects, the results obtained agreed with those presented by Mendes \& Komiyama (2003). The authors also found no effect of the genetic strain on meat quality parameters and the results are similar to those observed by Pavan et al. (2003) and 19\% is below the threshold values that define the PSE meat (Schneider et al., 2005) for losses above $25 \%$.

The results found for weight loss by cooking shearing force differ to the ones observed by Santos et al. (2005) who noted the influence of genetic strain on the shear strength of the meat. Pavan et al. (2003) describe shear force limits to soft broiler breasts meat within a range of variation between 1.91 and $2.23 \mathrm{kgf}$ per $\mathrm{cm}^{2}$. Higher values for shear strength, as found by Huallanco (2005) (3.0 to $8.2 \mathrm{kgf}$ per $\mathrm{cm}^{2}$ ), might be associated with the factors that cause stress in broilers during the antemortem, such as time and distance of transport between the farmhouse and the slaughterhouse.

Individual organoleptic characteristics such as texture and flavor of meat are more influenced by age than by other factors such as weight, genetic or sex (Takahashi et al., 2012). The definition that diverges from results reported by Ricard \& Touraille (1988) cited by Julião (2003), where the pectoral muscle of females was more tender than in males, and the flavor of the meat was more prominent in male broilers.

\section{CONCLUSIONS}

The use of lemongrass infusion in water preslaughter diet did not affect the carcass quality, and broiler meat neither changed the stressful condition of broilers.

\section{ACKNOWLEDGEMENTS}

This research was funded by the Center for Research in Nutrition and Monogastric Production of UFGD and CAPES granted the scholarship.

\section{REFERENCES}

Barbosa Filho JAD, Vieira FMC, Silva IJO, Garcia DB, Silva MAN, Fonseca BHF. Transport chickens: characterization of the microclimate in charge during the winter. Revista Brasileira de Zootecnia 2009;38:2442-2446.

Bressan MC, Beraquet NJ. Factors effects pre-slaughter on the quality of chicken breast meat. Ciência e Agrotecnologia 2002;26:049-1059.
Cornforth D. Color - Its basis and importance. In: Pearson AM, Dutson TR editors. Quality attributes and their measurement in meat, poultry and fish products. Glasgow: Academic and Professional; 1994. p.34-78.

Cruz MES, Nozaki MH, Batista MA. Plantas medicinais e alelopatia. Revista Biotecnologia Ciência \& Desenvolvimento 2000;28-34 [cited 2004 Mar 25]. Available from: http://www.biotecnologia.com.br/revista/ bio15/15.

Delgado-Suárez EJ, Rubio-Lozano MS, Toledo-López VM, TorrescanoUrrutia GR, Ponce-Alquicira E, Huerta-Leidenz N. Quality traits of pork semimembranosus and triceps brachii muscles sourced from the United States and Mexico. Meat Science 2016;122:125-131.

Droval AA. Meat PSE (Pale, Soft, Exudative) in broilers: Physical and sensory parameters evaluation and analysis of polymorphisms in specific regions of the gene RyR [thesis]. Londrina (BR): Agrarian Science College; 2011.

Fragoso SP. Evaluation of physico-chemical characteristics of the bullfrog meat (Lithobates catesbeianus) lyophilized normal pigmentation and albino [dissertation]. João Pessoa (PB): Universidade Federal da Paraiba; 2012.

Hamm R. Biochemistry of meat hydration. Advanced Food Research1960;10:335-443.

Huallanco MBA. Application of carcasses and cuts classification system and after slaughter effect of quality broiler cuts created inalternative system [dissertation]. São Paulo (BR): Universidade de São Paulo; 2005.

Julião AM. Evaluation of the centesimal composition and sensory acceptance the meat of commercial lines broilers and colonial type commercialized in retailer level [dissertation]. Niteroi (RJ): Universidade Federal Fluminense; 2003.

Lara JAF, Senigalia SWB, Oliveira TCRM, Dutra IS, Pinto MF, Shimokomaki M. Evaluation of survival of Staphylococcus aureus and Clostridium botulinum in charqui meats. Meat Science 2003;65:609-613.

Maganhini MB, Mariano B, Soares AL, Guarnieri PD, Shimokomaki M, Ida El. Meat PSE (Pale, Soft, Exudative) and DFD (Dark, Firm, Dry) in swine loin in an industrial slaughter line. Ciência e Tecnologia de Alimentos 2007;27:69-72.

Mendes AA, Komiyama CM. Management strategies broiler aiming at carcass quality and meat. Revista Brasileira de Zootecnia 2011;40:352357.

Mendes AA, Moreira J, Garcia RG. Quality of broiler chicken breast meat. Revista Nacional de Carnes 2003;27:138-144.

Mollete C, RemignonH, Babile R. Maintaining muscles at a higherpostmortem temperature induces PSE - like meat in turkey. Meat Science 2003;63:525-532.

Moreira J, Mendes AA, Garcia EA. Performance evaluation, carcass yield and breast meat quality in broilers of conformation versus conventional lineages. Revista Brasileira de Zootecnia 2003;32:1663-1673.

Negrelle RRB, Gomes EC. Cymbopogon citratus Stapf: chemical composition and biological activities. Revista Brasileira de Plantas Medicinais 2007;9:80-92.

Paranhos da Costa MJR. Behavior and welfare. In: Macari M, Furlan RL, Gonzales E, editors. Avian physiology applied in broilers. Jaboticabal: Funep; 2008. p.327-348.

Pavan AC, Mendes AA, Oliveira EG, Denadai JC, Garcia RG, Takita TS. Effect on the lineage and dietary lysine level the meat quality of broiler breast. Revista Brasileira de Zootecnia 2003;32:1732-1736.

Pereira DF, Salgado DD, Nääs IA, Penha NL, Bighi CA. Effect of air temperature, lineage and period of the day in the frequencies of 
Garcia RG, Royer AF, Nääs IA, Borille R, Santana M, Caldara FR occurrences and behavioral expression times of heavy breeders. Engenharia Agrícola 2007;27:596-610.

Pilecco M, Almeida Paz ICL, Tabaldi LA, Nääs IA, Garcia RG, Caldara FR, et al. Influence of genetic and environmental factors and management on the incidence of dorsal scratches in broilers. Revista Agrarian 2011;4:352-358

Praxedes CIS. Exudation of gel in cooking in normal broiler breast meat, PSE e DFD [dissertation]. Niteroi (RJ): Universidade Federal Fluminense; 2007.

R Core Team. A language and environment for statistical computing. Vienna: R Foundation for Statistical Computing; 2012. Available from: http://www.r-project.org.

Ribeiro CS. Welfare animal as aprerequisite in the production of broilers [specialization in hygiene and inspection of animal products]. Rio de Janeiro (RJ): Universidade Castelo Branco; 2008. 47 p.

Ricard FH, Touraille C. Influence of gender on the sensory characteristics of chicken meat. Archiv für Geflügelkunde1988;52:27-30.

Rocha JSR, Lara LJC, Baião NC. Production and animal welfare: ethical and technical aspects of intensive poultry production. Ciência Veterinária nos Trópicos 2008;1:49 -55.
Roque-Specht VF, Simoni V, Parise N, Cardoso PG. Evaluation of water retention capacity in broiler breasts on the final $\mathrm{pH}$. Revista Brasileira de Agroecologia 2009;15:77-87.

Santos AL, Sakomura NK, Freitas NR, Fortes CMLS, Carrilho ENVM, Fernandes JBK. Study of growth performance, carcass yield, and meat quality three broiler lineages. Revista Brasileira de Zootecnia 2005;34:1589-1598.

Schneider JP, Oda HI, Olivo R, Shimokomaki M. Meat DFD of broilers. Revista Nacional da Carne 2005;29:26-31.

Takahashi SE, Mendes AA, Mori C, Pizzolante CC, Garcia RG, Almeida Paz $I C L$, et al. Meat quality of broilers colonial and industrial type. Revista Científica Eletrônica de Medicina Veterinária 2012;9:7-18.

Torres TR, Lüdke MCMM, Maciel MIS, Lüdke JV, Nassu RT, Souza EJO. Sensory attributes of broilers fed cottonseed meal extruded by simplified quantitative descriptive analysis and the triangular test. Revista Brasileira de Ciência e Agrotecnologia 2011;6:174-180.

Zenebon O, Pascuet NS, Tiglea P. Physico-chemical methods for food analysis. In: Zenebon O, Pascuet NS, Tiglea P, editors. São Paulo: Instituto Adolfo Lutz; 2008. p.1020. 
